Hydrol. Earth Syst. Sci. Discuss.,

https://doi.org/10.5194/hess-2020-235-AC1, 2020

(C) Author(s) 2020. This work is distributed under

the Creative Commons Attribution 4.0 License.

\title{
Interactive comment on "Uncertainty of simulated groundwater recharge at different global warming levels: A global-scale multi-model ensemble study" by Robert Reinecke et al.
}

\section{Robert Reinecke et al.}

reinecke@bafg.de

Received and published: 28 August 2020

Please see attached PDF for a full rebuttal including a markup document of proposed changes to the manuscript.

Please also note the supplement to this comment: https://hess.copernicus.org/preprints/hess-2020-235/hess-2020-235-AC1supplement.pdf

Interactive comment on Hydrol. Earth Syst. Sci. Discuss., https://doi.org/10.5194/hess-2020- 